\title{
Business ethics in the UK
}

Christopher J. Cowton

Huddersfield Business School, University of Huddersfield, UK

\section{Introduction}

With about 65 million inhabitants, ${ }^{1}$ the UK comprises less than $1 \%$ of the globe's population. Nevertheless, it is a significant economy, a member of the Group of Eight (G8) industrialized nations, and London is currently the largest financial centre in Europe and dominates worldwide in certain financial areas (Goddard and Wilson 2016). The UK's business framework is well established and influential; for historical reasons - namely the British Empire, which at its zenith covered about a quarter of the world's population - its institutions and business practices have had influence out of line with its current economic power. Since 1974 it has in turn been affected as a member of the European Union (EU). However, at the time of writing it is in the process of leaving the EU following the referendum of 2016 when approximately $52 \%$ of those who cast their vote expressed a preference for 'Brexit'. How this will affect the strength of the economy, including the international position of the City of London, remains to be seen. The eventual implications of Brexit for regulatory frameworks and business practice are also uncertain, but like many relatively open economies, the UK is highly integrated into global trade systems, with the pressures towards convergence that this implies.

Nevertheless, there are some characteristics of UK business practice and regulation that, if not unique, are at least notable, especially because of their influence upon policy and practice elsewhere. This article therefore begins with a consideration of the legal framework for companies in the UK that both enables and constrains corporate activity. The next section examines the UK approach to corporate governance which, although of much more recent origin, has also had significant international influence. The third main section discusses some of the current ethical issues regarding UK business. The Conclusion completes the article.

\section{The legal framework}

The framework within which companies operate constrains or enables what might be viewed as 'good' business practice. Indeed, without the legal framework, companies would not exist; they are a legal creation. The UK was the first modern 'industrialized' economy and hence the first to develop institutions and practises that are now widely taken for granted, in particular the limited liability company possessed of a separate legal personality. Indeed, this innovation could be said

\footnotetext{
${ }^{1}$ www.ons.gov.uk/peoplepopulationandcommunity/populationandmigration/populationestimates, accessed 02 October 2017
} 
to have been a major influence upon industrialization and economic development, rather than just a result of it, since it encourages the investment of large amounts of risk capital and enables continuity of operation. This institutional framework thus has benefits, but it is also carries with it certain risks, including the possibility of excesses or abuse.

Nineteenth century judges were particularly concerned about the ability of those engaged in business to walk away from debts when a company failed, protected by the corporate 'veil' (i.e. the debts were those of the company itself). Well aware of the hazards of limited liability when compared with sole proprietorship or partnership, the courts, as they developed company law in tandem with statutory provisions, sought to protect creditors (Cowton 2011). It could be argued that incorporation with limited liability is still abused today, such as when business people recklessly leave creditors out of pocket or buy the company out of administration in a 'pre-pack' set up in their favour - perhaps more than once.

As it developed, UK company law influenced many other countries, including the USA and, in particular, members of the former British empire such as Australia and India. Milestones during the past century have included the Companies Acts of 1948 and 1967 and, subsequently, various pieces of legislation following the UK's 1973accession to the European Union (as it is now). These developments were consolidated in the Companies Act 1985, but this has now been superseded by the Companies Act 2006, which at the time was the longest Act in British Parliamentary history. One of the features of the increasingly voluminous and complex body of statute law is a vast growth in the quantity and scope of information provided in, and with, the audited financial statements, thus extending accountability - particularly to shareholders. Yet still there exist calls for greater 'transparency', partly because of reduced confidence in summarized accounting numbers and partly because of interest in particular issues, including executive pay.

Many popular understandings of the position of shareholders, such as their owning the business, are legally and conceptually flawed (Cowton 2011). In the UK the legal tradition is that the primary duty of the directors is to the company itself. However, this duty can be interpreted as a duty to the body of shareholders as a whole, and it is certainly the case that the UK - like many other 'AngloSaxon' regimes - is strongly shareholder-oriented. The rights of creditors can be asserted when a firm is in financial distress (Cowton 2011), but in everyday practice shareholder primacy holds sway.

However, the Companies Act 2006 does appear to hint at a possible modification of shareholder primacy, at least in the eyes of some commentators, who view it as a piece of pro-stakeholder legislation. For Section 172(1) of the Act states that directors must have regard to (amongst other matters): the interests of the company's employees; the need to foster the company's business relationships with suppliers, customers and others; and the impact of the company's operations on the community and the environment. It can be argued, though, that the Section is too vague to 
have any real legal effect, and to the extent that its message is clear, it reasserts shareholder primacy, because it states that directors should have regard to the previously mentioned factors when acting in the way they consider, in good faith, would be most likely to promote the success of the company. At most, therefore, the Section seems to be a call for 'enlightened shareholder value', which arguably is what acting 'in the interest of the company' should consist in anyway. Indeed, a member of the steering group whose report led to the passage of the Act comments that they thought there was a strong case for making explicit the law's true character, having come to the opinion that it was widely misunderstood in too narrow and short-term a way (Mayo 2008) which presumably is why the first factor that directors are required to have regard to, before the mention of any stakeholders in S.172(1), is 'the likely consequences of any decision in the long term'. Thus the Section is consistent (at most) with instrumental stakeholder theory rather than normative stakeholder theory. It seems to resonate well with the UK Stewardship Code, ${ }^{2}$ published by the Financial Reporting Council in 2010, the aims of which are to support the efficient exercise of institutional investors' governance responsibilities and to enhance the quality of their engagement with companies, with a view to improving long-term returns.

The directors are also to have regard to the desirability of the company maintaining a reputation for high standards of business conduct, which seems to imply that the law is seeking to promote good business ethics. Again, this might be considered too vague to have any real impact on behavior, particularly given the reluctance of the courts to challenge directors' judgment; and it is oriented towards enlightened shareholder value rather than for its own sake (note the reference to 'reputation'). Nevertheless, it is interesting for at least two reasons: first, that it should - like various stakeholders - be mentioned at all within company law; and second, it reflects a view that, in practice, some UK companies are missing out on opportunities to pursue the 'business case for ethics' and hence behaving less well than they might easily choose to do.

Furthermore, there has been some debate about how to enhance the provisions of S.172, including the idea of providing narrative reporting that explains to shareholders and other stakeholders about the implementation of S.172 duties. However, any developments now seem likely to fall short of requiring companies to have worker representation on the board of directors just as proposals along such lines in the Bullock Report of 1977 on industrial democracy were not taken up.

\footnotetext{
${ }^{2}$ frc.org.uk/investors/uk-stewardship-code, accessed 02 October 2017
} 


\section{Codifying corporate governance}

While the law sets the framework for corporate governance - and did so long before the term itself became commonplace - the past quarter of a century or so has seen the growth of a movement to address perceived problems with the governance of companies listed on the stock market. Although shareholder primacy holds in principle in the UK, both incompetence and the kinds of problems highlighted by agency theory can mean that companies are not always run effectively in the interests of shareholders. Following certain 'scandals' in the 1980s, such as Polly Peck, BCCl and the Robert Maxwell affair (Avison and Cowton 2012), corporate governance emerged as a significant issue and led to the establishment of the Cadbury Committee on the Financial Aspects of Corporate Governance (Cadbury 1992). The original report and subsequent developments have been influential in other countries. The UK Corporate Governance Code (as it now is), ${ }^{3}$ which is overseen by the Financial Reporting Council, contains broad principles and more specific provisions. Listed companies are required to report on how they have applied the main principles of the Code, and either to confirm that they have complied with the Code's provisions or to provide an explanation - the so-called 'comply or explain' approach. This is very much in keeping with the British common law approach, rather than (mainland European) codification - principles rather than rules, substance over form, and the spirit rather than the letter (at least in theory).

The scope of successive versions of the code (or different codes) has broadened over the years (e.g. coverage of risk resulted from the Turnbull Report 1999 on internal control), but it still has a shareholder focus. Nevertheless, in addition to influencing corporate governance frameworks elsewhere in the world, the code has also had impacts beyond the listed company sector. Partly because of some recent cases, such as the pension problems arising from the failure of the bhs retail chain, there are discussions about introducing a corporate governance code for the largest privately-held companies. Moreover, various types of not-for-profit organization - including charities and universities - have witnessed the introduction of governance codes, especially as they have been encouraged, if not required, to become more professional and 'business-like'.

Finally, in relation to governance, board diversity has become a high-profile issue, for reasons related both to effectiveness (the 'business case') and justice. Much of the focus to date has been upon gender diversity, but there are also signs of growing debate about other forms of diversity, including ethnicity. So far in the UK, there has been resistance to the idea of mandatory quotas, but this is an area in which guidelines and scrutiny, already in evidence, are likely to increase pressure for change.

\footnotetext{
${ }^{3}$ frc.org.uk/directors/corporate-governance-and-stewardship/uk-corporate-governance-code , accessed 02 October 2017
} 


\section{Some current issues and influences}

The continued evolution of the UK's company law and corporate governance framework suggests that it is adaptable but also that it is not perfect. Moreover, as explained, it is largely focused on shareholders rather than other stakeholders. However, it should be noted that many stakeholders are covered by other branches of law (employment, health and safety, consumer, environmental, discrimination etc.). Some businesses will readily uphold or even exceed their legal duties, while others will carelessly or deliberately not do so. This itself is an ethical issue, and so it is not surprising that ethical debate about business at any given time deals not only with issues already covered by legislation or other regulations, but also other issues that might be so in the future, depending on the strength and longevity of the criticisms of companies, as well as their response to those criticisms.

Some insight into the current ethical issues is provided by the Institute of Business Ethics' (IBE) annual overview of major ethical concerns and lapses recorded in its weekly media monitoring. The method used is biased towards large companies - which usually have a code of ethics or similar nowadays - and is dependent upon what the news media are choosing to report. It therefore does not necessarily reflect the issues (both good and bad) relating to SMEs, which are the vast majority of companies. Nevertheless, it is useful as an indicator of at least some of the issues that seem to be of concern in the country; and if the reporting of those issues persists in public media, they are likely to be prime candidates for future regulation or even legislation.

From the 604 different news stories recorded by the IBE in 2016, the most prominent sector (with 156 stories) was banking and finance, which reflects not only its size in the UK but also the scrutiny to which it has been subjected since the global financial crisis. Many of the stories related to financial crime, including insider trading and money laundering. Interestingly, although in the 2016 edition of Transparency International's $(\mathrm{TI})$ Corruption Perception Index, the UK was ranked $10^{\text {th }}$ out of 176 countries, ${ }^{4}$ TI has noted concern about money laundering, which it considers to have been fuelling the boom in London property prices. ${ }^{5}$ Considerable attention was also paid in the media stories to executive compensation, especially where packages were considered to be excessive in relation to performance. This comes on top of much bad publicity for banks in recent years; they have had to make major reparation for the mis-selling of personal protection insurance (PPI) policies, interest rate swaps and endowment mortgages, as well experiencing the LIBOR scandal.

The retail sector was also prominent in the IBE survey (75 stories), with concern about, inter alia, delayed payments to suppliers. Although the UK now has its third prompt payment code in

\footnotetext{
${ }^{4}$ www.transparency.org/country/GBR, accessed 03 June 2017

5 www.transparency.org/news/feature/property in the uk a home for corrupt money, accessed 02 October 2017
} 
operation, ${ }^{6}$ its voluntary nature and limited take-up seem to undermine its effectiveness. Some retail companies were also criticized for their poor pay and employment conditions, which was one of the four 'top' issues across sectors according to the IBE media analysis. (The others were: bribery and corruption; fraud; and treatment of customers.) Questionable use of 'zero hours contracts' and other practises make it difficult for some workers to flourish. This possibly reflects some particular features of the UK economy, especially following the global financial crisis.

At the time of writing (late 2017), total employment is at record levels and unemployment is measured at less than $5 \%$ of the workforce. In a time of sluggish growth, this would appear to be a good thing, but the corollary (an arithmetic one, if not a necessary economic one) is that productivity is relatively poor when compared with many other developed economies. To some extent this probably reflects the longstanding problem that a significant section of the population has low skills levels, with technical education and training relatively weak by international standards. However, it might also reflect the relatively high levels of immigration in recent years, with migrants often competing for jobs below their home qualification levels. If the level of immigration does indeed fall significantly post-Brexit, which seems likely, lower paid workers might find their position improved, with more local labour markets clearing at above the National Minimum Wage (introduced in 1999). A report published in 2017, chaired by Matthew Taylor at the request of the Prime Minister, Theresa May, looked at ways in which all work in the economy might be made fair and decent, with scope for development and fulfilment. ${ }^{7}$ Whether or not its recommendations have any effect on policy, the review provides a useful summary of the challenges faced by many workers, which Brexit - if it helps - is unlikely to eradicate completely. However, it should be noted that not all companies, even in the industries highlighted, are mired in ethical issues. Many excellent companies, both large and small, operate across the economy. In pursuing ethical policies and practices, they face some challenges, but there are various sources of support available to them. Mention has already been made of the Institute of Business Ethics and Transparency International. The UK also has a well-developed network of professional bodies in many fields related to business, whose members are - or should be - expected to uphold higher standards than those required by ordinary morality and the law. A more recent development is that a large proportion of university students study business in some form, and such courses increasingly contain at least some business ethics topics, encouraged by the growing interest of UK business schools in obtaining international accreditation and the increased numbers that have signed up to the UN's Principles for Responsible Management Education. Such teaching is not necessarily under the heading of 'business ethics' though; titles such as 'corporate (social) responsibility' and 'governance' are also in evidence.

\footnotetext{
${ }^{6}$ www.promptpaymentcode.org.uk/, accessed 02 October 2017

7 www.gov.uk/government/publications/good-work-the-taylor-review-of-modern-working-practices, access 02 October 2017
} 


\section{Conclusion}

The UK has a relatively well regarded business framework that, for reasons of history as much as its strengths, has had considerable international influence. Nevertheless, public debate and criticism indicate several areas of ethical concern, in particular for workers who do not possess highly valued skills. Many of those workers will have voted for Brexit, but whether that leads to an improvement in their conditions remains to be seen.

\section{References}

Avison L, Cowton CJ (2012) UK audit committees and the Revised Code. Corporate Governance: International Journal of Business in Society 12(1), 42-53

Cadbury A (chair) (1992) Report of the Committee on the Financial Aspects of Corporate Governance. Gee, London

Cowton CJ (2011) Putting creditors in their rightful place: corporate governance and business ethics in the light of limited liability. Journal of Business Ethics 102 (1/S1) 21-32

Goddard J, Wilson JOS (2016) Banking: a very short introduction. Oxford: Oxford University Press Mayo C (2008) Directors' duties. In: Rushton K (ed) The business case for governance. Cambridge University Press, Cambridge, p 119-145

\section{Cross-References}

Immigration and Business Ethics

Bribery

Codes of Conduct/Codes of Ethics, Business Principles

European Union

Board Diversity

Corporate Governance 